\title{
Study the effect of Peganum harmala L. Alkaloids Extract in-vivo as Anti-Inflammatory Agent
}

\author{
Usama H. Ramadhan* Basim J. Hameed Zainab T. Khalf \\ Department of Pharmaceutical Chemistry-College of Pharmacy- University of Basrah \\ *E-mail: usama_ramadhan@yahoo.com
}

\begin{abstract}
The Peganum harmala (L.) have some activities, the alkaloids are from indole series expected have antiinflammatory activity. The alkaloids were extracted by two methods first by ethanol, the second by acidify water with acetic acid. The extracts were tested for anti-inflammatory test by carrageenan induced inflammation test on mice, and the percentage of inflammation inhibition was calculated. The drug (diclofenac sodium) was used as standard drug. The alkaloids extracted by acidify method shows significant activity ( $p<0.01)$ at 2 and 3 hours. The percentages of inhibition were approximated to that were estimated of diclofenac sodium drug. The results indicated the alkaloids that were extracted as salts according to second method were more potent towards inflammation redaction.
\end{abstract}

Key words: Peganum harmala, Alkaloids, Anti-inflammatory, and Alkaloids salts.

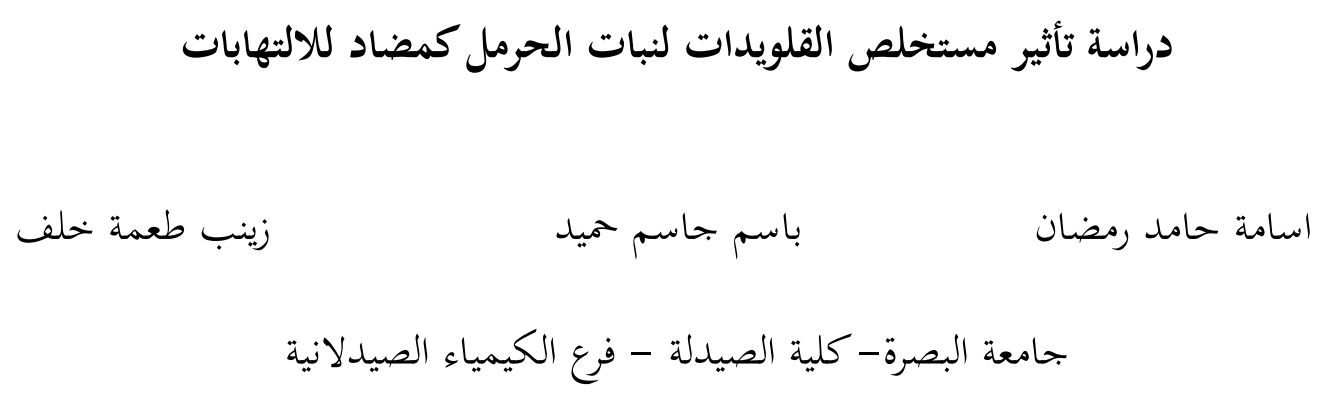

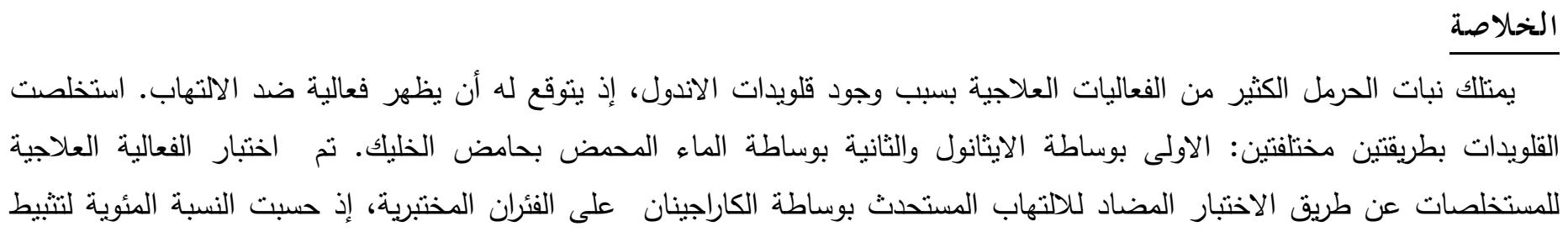


الالتهاب. أستعمل الصوديوم دايكلوفيناك كدواء مرجعي ـ المستخلص الذي استخلص بوساطة الماء المحمض اثبت فعالية معنوية بعد الساعة

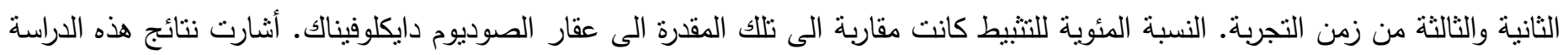
إلى إن القلويدات المستخلصة على شكل املاح وفقا لطريقة الاستخلاص الثانية كانت أكثر فعالية تجاه تثبيط الالتهابات .

\section{Introduction}

Medicinal plants are believed to be an important source of new chemical substances with potential therapeutic effects. Thus study of plant species that traditionally have been used as pain killers should still be seen as a logical search strategy, in research for new analgesic drugs ${ }^{(1,2)}$. Harmal alkaloids are $\beta$-carboline system derivatives which frequently occur in the indole alkaloid series. Harmine and harmaline are the main alkaloids of peganum harmala L. (Syrian rue) is a wild growing flowering plant belonging to the Zygophylaceae family and is found an abundantly in middle east and North Africa ${ }^{(3,4)}$. Alkaloids of harmala are valued for their interesting chemistry, pharmacological importance and therapeutic potential. They possess antitumor, antileishmanial, anti-HIV, antibacterial, antifungal activities and MAO-inhibition ${ }^{(5,6)}$. They have also been known to interact with $\alpha 2$-adrenoceptor subtypes ${ }^{(7)}$. Figure 1 show the main alkaloids of peganum harmala with systematic names ${ }^{(8-10)}$. Inflammatory mediators such as prostaglandins (PGs), leukotrienes (LTs) and tumour necrosis factor-alpha (TNF- $\alpha$ ) are implicated in a wide variety of diseases such as rheumatoid arthritis (RA), osteoarthritis (OA), asthma, atherosclerosis, different types of cancers and diseases of the central nervous system ${ }^{(11,12)}$.

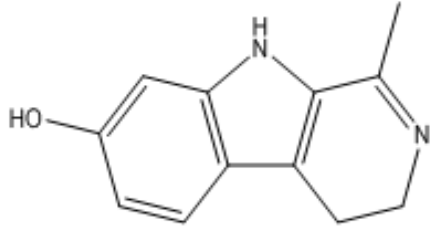

1-methyl-4,9-dihydro-3H-pyrido[3,4- $b]$ indol-7-ol

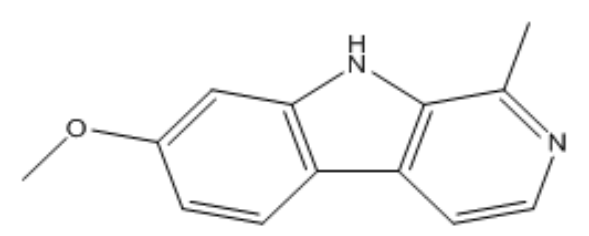

7-methoxy-1-methyl-9H-pyrido[3,4- $b]$ indole

Harmine

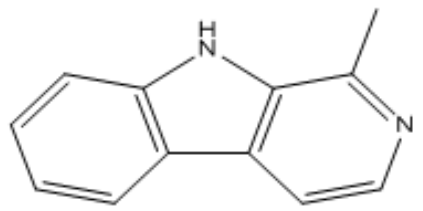

1-methyl-9H-pyrido $[3,4-b]$ indole

Harmane

Harmaline<smiles>OC1CCN2Cc3ccccc3N=C12</smiles>

1,2,3,9-tetrahydropyrrolo[2,1-b]quinazolin-3-ol

Vasicine

Figure 1: The structures of main alkaloids of peganum harmala L. 
Traditional Non Steroidal Anti-Inflammatory Drugs (NSAIDs) such as aspirin, ibuprofen and diclofenac that exhibit non-selective COX inhibition represent some of the most widely prescribed NSAIDs to relieve short term fever, pain and inflammation ${ }^{(13,14)}$. The purpose of preset study was to determine the peganum harmala antiinflammatory activity of the alkaloids extracts.

\section{Methods}

\section{The Water Extract preparation}

The powder of seeds $(30 \mathrm{gm})$ extracted with $(125 \mathrm{ml})$ of distilled water, the mixture were reflux at $100{ }^{\circ} \mathrm{C}$ for $(1 \mathrm{hr})$ then filtrate. The supernatant was evaporated at room temperature to the dryness. (15)

\section{The Alkaloids Extract Preparation}

The defating progress by cold extract of $50 \mathrm{gm}$ of peganum harmala $\mathrm{L}$. seeds powder with $150 \mathrm{ml}$ of $\mathrm{n}$-hexane for $(3 \mathrm{hr})$. The alkaloids were extracted by two methods:

(1) The dry defatted seeds of peganum harmala $(30 \mathrm{gm})$ were extracted with $(250 \mathrm{ml})$ of $(5 \%)$ acetic acid in $(60 \%)$ ethanol, the mixture was heated on hot plate for $(3 \mathrm{hr})$ at $\left(50{ }^{\circ} \mathrm{C}\right)$. The extract were centrifuge and the filtrate were collected and concentrated to $(20 \mathrm{ml})$, the solution were alkaline by adding conc. $\mathrm{NaOH}$, then filtered the crude alkaloids were precipitate. The crude alkaloids were washed with $(1 \%) \mathrm{NH}_{4} \mathrm{OH}$ and then dried. ${ }^{(15)}$

(2) The dry defatted seeds of peganum harmala $(30 \mathrm{gm})$ were extracted with $(125 \mathrm{ml})$ of $(10 \%)$ acetic acid in distilled water, the mixture was heated for $(30 \mathrm{~min})$ at $\left(50{ }^{\circ} \mathrm{C}\right)$. The extract was centrifuged and the filtrate were collected and concentrated to $(20 \mathrm{ml})$, the solution alkalinised by adding $10 \mathrm{ml}$ conc. $\mathrm{NaOH}$, then filtered the crude alkaloids were precipitate. The crude alkaloids were washed with $25 \mathrm{ml}$ of $(1 \%) \mathrm{NH}_{4} \mathrm{OH}$ and then dried at room temperature to dryness. ${ }^{(15)}$

\section{$\underline{\text { Animals }}$}

Male and female albino mice weighing 25-30 gm were used, the mice have access of food and water, maintained on 12-hours light/dark cycle with controlled temperature $\left(25^{\circ} \pm 2\right)$ before and during the experimental time.

\section{The anti-inflammatory test}

The acute hind paw oedema was produced by injecting $20 \mu \mathrm{l}$ of carrageenan (prepared as $1 \%$ suspension in sterile normal saline) locally into the plantar aponeurosis of the right hind paw of mice. Extracts was administered to three different groups as following $50 \mathrm{mg} / \mathrm{kg}$ of the body weight water extract, alkaloids extract (1) and alkaloids extract (2) respectively. The other two groups served as negative and positive controls that received vehicle, normal saline $(1 \mathrm{ml} / \mathrm{kg}$, orally) and standard drug, diclofenac sodium $(50 \mathrm{mg} / \mathrm{kg})$ respectively. Extracts were administered $1 \mathrm{hr}$ prior to the injection of carrageenan. The paw circumference was measured in digital micrometer device at hourly interval for $3 \mathrm{hr}$. Antiinflammatory activity was measured as the percentage reduction in oedema level when drug was present, relative to control as shown in table 1. Increase in the paw oedema volume was considered as the difference between 1 and $3 \mathrm{hr}$. Percent inhibition of oedema volume between treated and control groups was calculated as follows:

$\%$ Inhibition $=(1-\mathrm{Vt} / \mathrm{Vc}) \mathrm{X} 100$

Where $\mathrm{Vt}$ and $\mathrm{Vc}$ are the relative changes in the oedema of the test and control respectively. ${ }^{(16)}$

\section{Experimental design}

The animals were divided into five groups of six animals in each group:

Group I: - Negative control; receive normal saline. Group II: - received Water Extract $50 \mathrm{mg} / \mathrm{kg}$, orally.

Group III: - received Alkaloids Extract in method one (Alk1) $50 \mathrm{mg} / \mathrm{kg}$, orally.

Group IV: - received Alkaloids Extract in method two (Alk2) $50 \mathrm{mg} / \mathrm{kg}$, orally.

Group V: - Positive Control received diclofenac sodium $50 \mathrm{mg} / \mathrm{kg}$, orally. 


\section{Statistical analysis}

The treatment groups' data were tested for one-way ANOVA student test to determine the significance of the differences between the control groups and mice treated with the tested extract. The value $(\mathrm{p}<0.01)$ regard as significant.

\section{Result}

The results of the anti-inflammatory activity were shows in table 1 . The results shows the water extract and alkaloid one not have significant activity on inhibition the inflammation in tested mice. Whereas the alkaloids extracted in method two shows significant inhibition to inflammation at 2 hour and 3 hour. The approach used $50 \mathrm{mg} / \mathrm{kg}$ of the body weight we can increase the activity by increased the doses. The percent of inhibition are approximated equals to diclofenac sodium for Alk2 at significant value were $100 \%$ and $115 \%$ respectively, where percent of inhibition of diclofenac sodium were $96 \%$ and $112 \%$ respectively. The figure 2 had shown the antiinflammatory test chart for extracts. As a result the Peganum harmala alkaloids were extracted in method two can be used as anti-inflammatory agents. Their concentration of alkaloids may be more than previous were extracted in method one.

Table 1: The results of anti-inflammatory activity test of extracts.

\begin{tabular}{|c|l|c|c|c|c|}
\hline \multirow{2}{*}{ Group } & \multirow{2}{*}{ Treatment } & \multicolumn{4}{|c|}{ The changes of paw size in $\mathrm{mm}}$. \\
\cline { 3 - 6 } & & zero & $1 \mathrm{hr}$ & $2 \mathrm{hr}$ & $3 \mathrm{hr}$ \\
\hline I & Control & $0 \pm 0.10$ & $0.981 \pm 0.12$ & $0.664 \pm 0.11$ & $0.643 \pm 0.11$ \\
\hline II & Water extract & $0 \pm 0.08$ & $0.817 \pm 0.11$ & $0.612 \pm 0.10$ & $0.595 \pm 0.07$ \\
\hline III & Alk1 extract & $0 \pm 0.11$ & $0.763 \pm 0.10$ & $0.560 \pm 0.17$ & $0.580 \pm 0.09$ \\
\hline IV & Alk2 extract & $0 \pm 0.10$ & $0.490 \pm 0.11$ & $0.330 \pm 0.10^{*}$ & $0.258 \pm 0.06^{*}$ \\
\hline V & Diclofenac sodium & $0 \pm 0.15$ & $0.403 \pm 0.15$ & $0.362 \pm 0.10^{*}$ & $0.276 \pm 0.09^{*}$ \\
\hline
\end{tabular}

Mean \pm SEM; $\mathrm{n}=6$ in each group; ${ }^{*} \mathrm{p}<0.01$ 


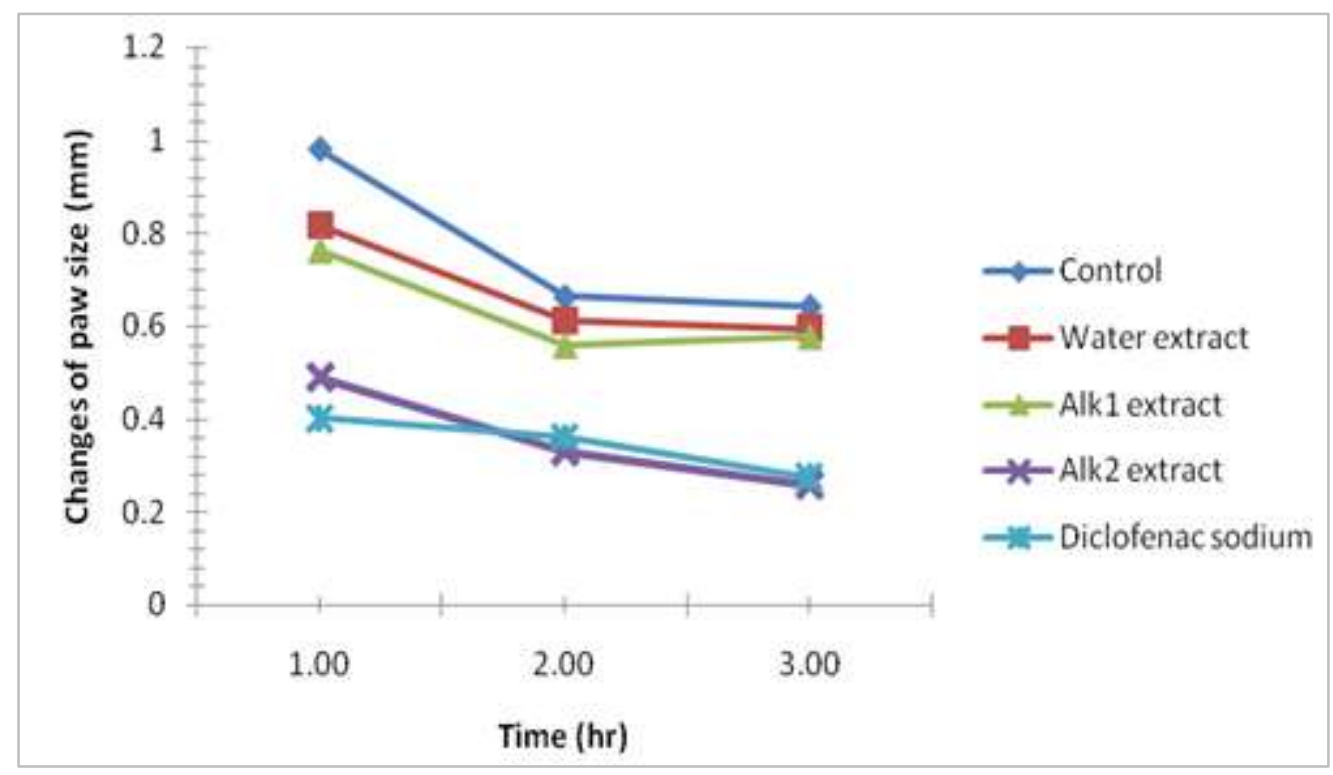

Figure 2: The Anti-inflammatory test designed for Extracts.

\section{Discussion}

The water extract was the first extract gives us an expectation that Peganum harmala plant not has anti-inflammatory activity. But further investigations for alkaloids extracts in two methods shown that the alkaloids in method two (Alk2) has anti-inflammation activity. The water extract was poorly extracted of alkaloids. That was clear that the active part is alkaloids extract, the first method was extracted the alkaloids in ethanol as a free week base, but in the second method the alkaloids extracted as salts (like diclofenac sodium) and this make it more absorbance and transport in the body. The alkaloids salts will leak to locate of inflammation site and make their effects to inhibit the inflammation. The anti-inflammatory activities overcome by compounds having a hetero-cyclic nucleus ${ }^{(17)}$. Histological examination of organs and tissues of treated rats were normal indicating that the extract has a low level of toxicity. However, sever local inflammatory reaction in the muscles at the site of injection was observed which caused a significant increase in the counts of leucocytes and neutrophil. This indicates that the intramuscular route is not a proper route of administration ${ }^{(18)}$, which indicates the gastric acid contributed in convert of alkaloids to alkaloids salts. Significantly high anti-inflammatory action of alkaloids extract Peganum harmala may be due to inhibition of the mediators of inflammation such as histamine, serotonin and arachidonic acid metabolism ${ }^{(19,20)}$. Further laboratory and clinical studies of this plant is required in order to understand better anti-inflammatory principles which will allow scientific community to recommend their use as an accessible alternative to synthetic drugs. The discovery of novel antiinflammatory targets continues to propel the development of small molecule therapeutics to treat inflammatory conditions. It is evident that a rational drug discovery effort that combines histamines and fragment screening techniques can provide novel small molecule ring templates that can be optimized by medicinal chemistry methods, to exhibit suitable in vivo activity and optimal pharmacokinetic properties (21). The Peganum harmala protected the animal against the carcinogenic effects. In addition, the observed hepatocytotoxicity was greatly reduced ${ }^{(22)}$. $P$. harmala can be assigned as a source of antibacterial compounds for treatment of infections caused by multi-drug resistant (MDR) bacterial pathogens and antileishmanial activities ${ }^{(23,24)}$. 


\section{Conclusions}

The Peganum harmala have anti-inflammatory activity and the active constituents are alkaloids, the type of extraction methods important to determine the activity. The alkaloids forms also important of determined the activity and in Peganum harmala should be as a salts structure.

\section{References}

1.Bisset $\mathrm{N}$ G. Herbal drugs and phytopharmacuticals, $2^{\text {nd }}$ ed. CRC press, New York, 2001, 342-344.

2.Monsef H R, Ghobadi A, Iranshahi M. Antinociceptive effects of Peganum harmala $L$. alkaloid extract on mouse formalin test. $\mathrm{J}$ pharm pharmaceut Sci. 2004, 7(1), 65-69.

3.Begum S, Ali F S, Siddiqui B S. An efficient mild and solvent free synthesis of benzene ring acylated harmalines. Molecules, 2010, $15,68-82$.

4.Zargari A. Medicinal plants. Vol 1, Tehran university press, Tehran, 1989, 637-639.

5.Cao R, Chen Q, Hou X, Chen H, Gunan H, Ma $\mathrm{Y}$, Peng $\mathrm{W}, \mathrm{Xu}$ A. Synthesis, acute toxicities and antitumor effects of novel 9substituted $\beta$-carboline derivatives. Bioorg med chem., 2004, 12, 4613-4623.

6.Abdel-Fattah A M, Matsumoto K, Murakami Y. Centralserotonin level dependent changes in body temperature following administration of tryptophan to pargyline and harmaline pretreated rats. Gen pharmacol, 1997, 28, 405-409.

7.Saleem A, Engstrom M Wurster S. Interaction of folk medicinal plant with human $\alpha_{2}-$ adrenceptor subtypes. Med plant Pakistan. 2001, 57, 332-338.

8.Mahmoudian M, Jalilpour $\mathrm{H}$ and Salehian $\mathrm{P}$, Toxicity of Peganum harmala: Review and a Case Report, IJPT, 2002, 1(1), 1-4.
9. Cao R, Peng W, Wang Z and Xu A, $\beta$-Carboline Alkaloids: Biochemical and Pharmacological Functions, Current Medicinal Chemistry, 2007, 14 (4), 479500.

10. Herraiza T, Gonzáleza D, Ancín-Azpilicuetac C, Aránb V J, and Guillén H, $\beta$-Carboline alkaloids in Peganum harmala and inhibition of human monoamine oxidase (MAO), Food and Chemical Toxicology, 2010, 48 (3), 839-845.

11. Charlier, $\mathrm{C}$ and Michaux, C. Dual inhibition of cyclooxygenase-2 (COX-2) and 5lipoxygenase (5-LOX) as a new strategy to provide safer nonsteroidal antiinflammatory drugs. Eur. J. Med.Chem. 2003, 38, 645-659.

12. Poeckel, D and Funk, C. D. The 5lipoxygenase/leukotriene pathway in preclinical models of cardiovascular disease. Cardiovasc. Res. 2010, 86, 243253.

13. Inotai A, Hanko B and Meszaro A, Trends in the non-steroidal anti-inflammatory drug market in six central-eastern European countries based on retail information. Pharmacoepidemiol. Drug Saf. 2010, 19, 183-190.

14. Meade E A, Smith W L and DeWitt D L, Differential inhibition of prostaglandin endoperoxide synthase (cyclooxygenase) isozymes by aspirin and other non-steroidal anti-inflammatory drugs. J. Biol. Chem. 1993, 268, 6610-6614.

15. Jarald $E$ E and Jarald $S$ E. Textbook of pharmacognosy and phytochemistry. CBS, New Delhi, 2009.

16. Chakma C S, Chakma R C and Ghosh T K, Anti-inflammatory activity of the fruit- 
seeds Madhuca longifolia (koenig), ARPB, 2011, 1(1), 56-59.

17. Amir M, Javed S A and Kumar H, Pyrimidine as anti-inflammatory agent: A review, Indian J of pharmaceutical sciences, 2007, 69 (3), 337-343.

18. Muhi-eldeen Z, Al-Shamma K J, Al-Hussainy T M, Al-Kaissi E N, Al-Daraji A M and Ibrahim $\mathrm{H}$, Acute Toxicological Studies on the Extract of Iraqi Peganum Harmala in Rats, European Journal of Scientific Research, 2008, 22 (4), 494-500.

19. Pountos I, Georgouli T, Bird H and Giannoudis P, Nonsteroidal anti-inflammatory drugs: prostaglandins, indications, and side effects, International Journal of Interferon, Cytokine and Mediator Research 2011, 3, 19-27.

20. Farouk L, Laroubi A, Aboufatima R, Benharref A and Chait A, Antinociceptive Activity of Various Extracts of Peganum harmala L. and Possible Mechanism of Action, IJPT, 2009, 8 (1), 29-35.
21. Rao P P, Kabir S N and Mohamed T, Nonsteroidal Anti-Inflammatory Drugs (NSAIDs): Progress in Small Molecule Drug Development, Pharmaceuticals 2010, 3, 1530-1549.

22. Hamden K, Masmoudi H, Ellouz F, El-Feki A and Carreau S, Protective effects of Peganum harmala extracts on thioureainduced diseases in adult male rat, Journal of Environmental Biology, 2008, 29(1), 7377.

23. Darabpour E, Bavi A P, Motamedi $\mathrm{H}$ and Nejad S M, Antibacterial activity of different parts of Peganum harmala L. Growing in Iran against multi-drug resistant bacteria, EXCLI Journal, 2011, 10, 252-263.

24. Rahimi-Moghaddam P, Ebrahimi S A, Ourmazdi H, Selseleh M, Karjalian M, HajHassani G, Alimohammadian M H, Mahmoudian M and Shafiei M, In vitro and in vivo activities of Peganum harmala extract against Leishmania major. J Res Med Sci, 2011, 16(8), 1032-1039. 